\title{
Determinan Kinerja Keuangan Dengan Size Sebagai Moderasi
}

\author{
Peni Setiyo Wati ${ }^{1}$, JMV Mulyadi ${ }^{2}$, Widarto Rachbini ${ }^{3}$ \\ Universitas Pancasila, \\ ${ }^{1}$ stypeny@gmail.com \\ 2jmv.mulyadi@univpancasila.ac.id \\ ${ }^{3}$ widarto@unipancasila.ac.id
}

\begin{abstract}
ABSTRAK
Penelitian ini bertujuan untuk menguji determinan kinerja keuangan dengan firm size sebagai moderasi. Faktor-faktor yang digunakan dalam penelitian ini terdiri dari : total asset turnover, likuiditas, net profit margin, leverage, firm age dan firm size. Firm size diproporsikan sebagai variabel pemoderasi pengaruh total asset turnover, likuiditas, net profit margin, leverage, firm age terhadap kinerja keuangan. Proxy kinerja keuangan dengan menggunakan Return On Assets (ROA). Fenomena dari penelitian ini adalah terdapat inkonsistensi dari hasil penelitian terdahulu dan terjadi pergerakan fluktuatif dari kinerja keuangan pada perusahaan industri manufaktur yang terdaftar di Bursa Efek Indonesia selama periode 2014 - 2017. Data penelitian ini diperoleh 208 perusahaan industri manufaktur yang terdaftar di Bursa Efek Indonesia (BEI) periode 2014-2017. Teknik analisis yang digunakan untuk pengujian hipotesis adalah dengan menggunakan program WARP-PLS 6.0. Hasil pengujian menunjukan bahwa total asset turnover, likuiditas, net profit margin, leverage, firm age, memiliki pengaruh signifikan terhadap kinerja keuangan. Firm size tidak memiliki pengaruh signifikan terhadap kinerja keuangan. Firm size memoderasi pengaruh net profit margin, firm age terhadap kinerja keuangan. Firm size tidak memoderasi pengaruh leverage terhadap kinerja keuangan. Firm size tidak memoderasi pengaruh total asset turnover, likuiditas, leverage terhadap kinerja keuangan.

Kata Kunci : Kinerja Keuangan, Total Asset Turnover, Likuiditas, Net Profit Margin dan Leverage.
\end{abstract}

\begin{abstract}
The purpose of this study is to to examine the determinants of financial performance with firm size as moderation. The factors used in this study consist of: total asset turnover, liquidity, net profit margin, leverage, firm age and firm size. Firm size is proportional as the moderating variable of the effect of total asset turnover, liquidity, net profit margin, leverage, firm age on financial performance. Proxy of financial performance using Return On Assets (ROA). The phenomenon of this study is there are inconsistencies from the results of previous researches and there are fluctuating movement of financial performance in manufacturing industry companies listed on the Indonesia Stock Exchange during the period 2014 - 2017. The data of this study were obtained 208 manufacturing industry companies listed on the Indonesia Stock Exchange (IDX) for period 2014-2017. The analysis technique used for hypothesis testing is using the WARP-PLS 6.0 program. The test results show that total asset turnover, liquidity, net profit margin, leverage, firm age, have a significant effect on financial performance. Firm size has no significant effect on financial performance. Firm size moderates the effect of net profit margin, firm age on financial performance. Firm size does not moderate the effect of leverage on financial performance. Firm size does not moderate the effect of total asset turnover, liquidity, leverage on financial performance.
\end{abstract}

Keywords: Financial Performance, Total Asset Turnover, Liquidity, Net Profit Margin and Leverage

ISSN: 2355-0295, e-ISSN: 2549-8932

http://ejournal.bsi.ac.id/ejurnal/index.php/ecodemica 
Naskah diterima: 29 Agustus 2019, direvisi: 01 September 2019, diterbitkan: 16 September 2019

\section{PENDAHULUAN}

Kinerja keuangan perusahaan dapat diartikan sebagai prospek atau masa depan, pertumbuhan, dan potensi perkembangan yang baik bagi perusahaan. Informasi kinerja keuangan diperlukan untuk menilai perubahan potensial sumber daya ekonomi, yang mungkin dikendalikan di masa depan dan untuk memperediksi kapasitas produksi dari sumber daya yang ada (Sundjaja \& Barlian, 2003). Evaluasi kinerja keuangan dapat dilakukan menggunakan analisis laporan keuangan, dimana data pokok sebagai input dalam analisis ini adalah neraca dan laporan laba rugi. Analisis kinerja keuangan pada dasarnya dibuat untuk melihat prospek dan risiko perusahaan. Prospek bisa dilihat dari tingkat keuntungan (profitabilitas) dan risiko bisa dilihat dari kemungkinan perusahaan mengalami kesulitan keuangan atau mengalami kebangkrutan. Dengan menggunakan rasio ini dapat mengetahui kelangsungan hidup perusahaan (going concern). Tingkat profitabilitas, menunjukkan sejauh mana kemampuan perusahaan dalam menghasilkan laba dengan modal yang dimilikinya (Maith, 2013). Total asset turnover merupakan rasio aktivitas yang digunakan untuk mengukur sampai seberapa besar efektivitas perusahaan dalam menggunakan sumber dayanya yang berupa asset. Semakin tinggi efisien penggunaan asset dan semakin cepat pengembalian dana dalam bentuk kas (Halim, 2007). Likuiditas menurut (Riyanto, 2001) adalah berhubungan dengan masalah kemampuan suatu perusahaan untuk memenuhi kewajiban finansialnya yang segera harus dipenuhi. Net Profit Margin merupakan rasio antara laba bersih setelah pajak terhadap penjualan. "Semakin tinggi $\mathrm{Net}$ Profit Margin, semakin baik operasi suatu perusahaan" (Syamsuddin, 2013.) Artinya semakin tinggi persentase laba bersih setelah pajak yang dihasilkan terhadap penjualan, maka semakin baik kinerja keuangan perusahaan tersebut. Leverage merupakan rasio yang digunakan dalam mengukur kinerja keuangan perusahaan kaitannya dengan seberapa besar aktiva yang diperoleh dari hutang dan modal (Widiyanti, M., \& Elfina, 2015). Perusahaan yang telah lama berdiri umumnya memiliki profitabilitas yang lebih stabil dibandingkan dengan perusahaan yang baru berdiri. Firm age digunakan untuk mengukur pengaruh lamanya perusahaan beroperasi terhadap kinerja keuangan (Chang, S.J. and Hong, 2002). Perusahaan-perusahaan yang memiliki ukuran yang lebih besar memiliki dorongan yang kuat untuk menyajikan tingkat profitabilitas yang tinggi dibandingkan dengan perusahaan-perusahaan yang lebih kecil karena perusahaan yang lebih besar diteliti dan dipandang dengan lebih kritis oleh para investor (Munawir, 2007). Penelitian ini mengambil sampel pada perusahaan industri manufaktur dikarenakan perusahaan sektor ini memberikan kontribusi yang cukup besar bagi negara dan sektor ini sedang mengalami tren penurunan yang telah terjadi dari tahun 2011 meski demikian sumbangan industri manufaktur terhadap penerimaan pajak negara dinilai masih cukup tinggi.

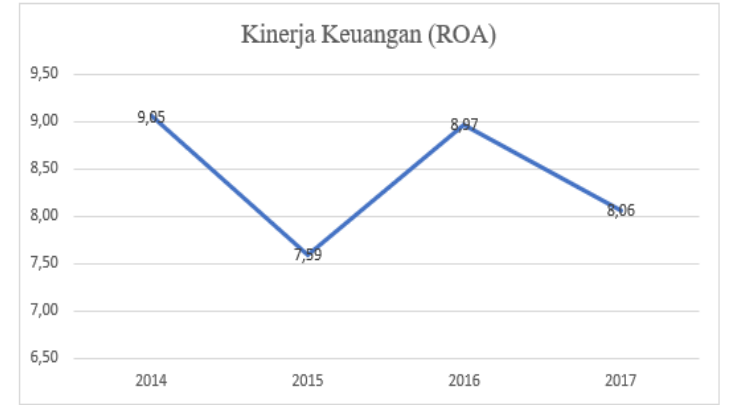

Sumber : www.idx.co.id, data diolah (2019)

Grafik 1. Pergerakan Rata-Rata Kinerja Keuangan Perusahaan Manufaktur yang Terdaftar di Bursa Efek Indonesia Peride 2014-2017

Dari grafik 1 terlihat bahwa rata - rata kinerja keuangan yang diproxy kan dengan ROA (Return On Assets) selama 4 (empat) tahun mengalami fluktuatif dan menunjukkan terjadinya ketidakkonsistenan pada sektor industri manufaktur. Pada tahun 2014 mengalami penurunan menjadi 9,05 , tahun 2015 mengalami penurunan menjadi 7,59, tahun 2016 mengalami kenaikan menjadi 8,97 dan pada tahun 2017 mengalami penurunan 
menjadi 8,06. Fluktuasi naik turun dan menjadi ketidakkonsistenan inilah yang merupakan fenomena utama dalam penelitian ini. Semakin besar ROA maka diartikan semakin bagus. Analisa penyebab kenaikan ROA diantaranya laba bersih naik aset total turun, laba bersih naik aset total stagnan, laba bersih dan aset total naik (kenaikan laba lebih besar dibandingkan aset total). ROA naik implikasinya berarti dengan sumber daya yang dimiliki (aset total), perusahaan mampu memaksimalkannya menjadi laba bersih. Sedangkan analisa penyebab ROA turun diantaranya laba bersih turun, aset total naik, laba bersih turun, aset total stagnan dan laba bersih dan aset total turun (penurunan laba bersih dibanding aset total).

\section{KAJIAN LITERATUR}

\section{Grand Theory}

\section{Theori Signaling/ Teori Sinyal}

Teori sinyal menunjukkan adanya asimetri informasi antara manajemen perusahaan dengan pihak-pihak yang berkepentingan dengan informasi. Isyarat merupakan tindakan yang diambil oleh manajemen perusahaan dan memberi petunjuk bagi investor tentang bagaimana manajemen memandang prospek perusahaan.

\section{Teori Akuntansi Positif}

Teori akuntansi positif merupakan varian dari teori ekonomi positif. Teori ini berkembang seiring dengan kebutuhan untuk menjelaskan dan memprediksi realitas praktik-praktik akuntansi yang ada di masyarakat dan untuk menjelaskan mengapa kebijakan akuntansi menjadi suatu masalah bagi perusahaan dan pihakpihak yang berkepentingan dengan laporan keuangan -what it is (Watts \& Zimmerman, 1986).

\section{Middle Range Theory \\ Teori Akuntansi Keuangan}

Akuntansi keuangan berorientasi pada pelaporan pihak eksternal (Martani D., 2012). Laporan yang dihasilkan dari akuntansi keuangan berupa laporan keuangan untuk tujuan umum (general purpose financial statement).

\section{Applied Theory}

1. Kinerja Keuangan
Kinerja berasal dari pengertian performance (Sugiyono, 2007). Ada pula yang memberikan pengertian performance sebagai hasil kerja atau prestasi kerja. Pengukuran kinerja keuangan perusahaan mempunyai beberapa tujuan diantaranya: Untuk mengetahui likuiditas, tingkat solvabilitas, tingkat profitabilitas atau rentabilitas, dan tingkat aktivitas usaha (Munawir, 2004). Kinerja Keuangan dapat dirumuskan sebagai berikut (Utami, Wikan Budi, 2016):

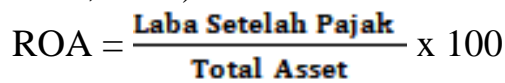

\section{Perputaran Total Aset / Total Asset} Turnover

TATO merupakan rasio pengelolaan aktiva terakhir, mengukur perputaran atau pemanfaatan dari semua aktiva perusahaan (J. F. Weston \& Brigham, 1989). Total asset turnover secara sistematis dapat dirumuskan sebagai berikut (Keown, Martin, Petty, \& Scott, 2008), (Sunjoko, Mary Ivana, 2016) :

TATO $=\frac{\text { Penjualan }}{\text { Total Aktiva }}$

\section{Likuiditas}

Likuiditas menyangkut masalah kemampuan suatu perusahaan untuk memenuhi kewajiban finansialnya yang segera harus dipenuhi (Riyanto, 2001). Formulasi dari current ratio (CR) adalah sebagai berikut (Sawir, 2001), (Hernawati, 2007):

Likuiditas $=\frac{\text { Aktiva Lancar }}{\text { Hutang Lancar }}$

\section{Net Profit Margin (NPM)}

Net Profit Margin merupakan rasio antara laba bersih setelah pajak terhadap penjualan. "Semakin tinggi Net Profit Margin, semakin baik operasi suatu perusahaan" (Syamsuddin, 2013.). formulasi dari net profit margin adalah sebagai berikut (Wardani \& Dewi, 2015) \& (Isbanah, 2015) :

$\mathrm{NPM}=\frac{\text { Earning After Interest and Tax (EAIT) }}{\text { Penjualan }}$

\section{Leverage (LEV)}

Leverage merupakan rasio yang digunakan dalam mengukur kinerja keuangan perusahaan kaitannya dengan seberapa besar aktiva yang diperoleh dari hutang dan modal (Widiyanti, M., \& Elfina, 2015). 


\section{LEV $=\frac{\text { Total Hutang }}{\text { Ekuitas }}$}

\section{Umur Perusahaan / Firm Age}

Perusahaan yang telah lama berdiri umumnya memiliki profitabilitas yang lebih stabil dibandingkan dengan perusahaan yang baru berdiri. Firm age digunakan untuk mengukur pengaruh lamanya perusahaan beroperasi terhadap kinerja keuangan (Chang, S.J. and Hong, 2002).

$\mathrm{AGE}=$ Laporan tahunan keuangan terakhir-Tahun perusahaan pertama go public.

\section{Ukuran Perusahaan / Size}

Terdapat tiga teori yang secara implicit menjelaskan hubungan antara ukuran perusahaan dan tingkat keuntungan (Kusuma, 2005).

SIZE = Ln (Total Assets)

\section{Model Penelitian}

Total Assets Turnover sendiri merupakan rasio antara penjualan dengan total aktiva yang mengukur efisiensi penggunaan aktiva secara keseluruhan. Perputaran total aset berpengaruh signifikan terhadap kinerja keuangan (Tjandra, 2015) , (Asiah, 2011), (Noor, 2011), (Haryo, Mercky, Amzul Rifin, 2017), (Dwiarti, 2016), (Suyono \& Gani, 2018) \& (Arisadi \& Djazuli, 2013). Perputaran total aset tidak berpengaruh signifikan terhadap kinerja keuangan (Wardani, A. K., \& Dewi, 2016), (Sunjoko, Mary Ivana, 2016) \& (Febriano, 2014).

Current ratio biasanya digunakan sebagai alat untuk mengukur keadaan likuiditas suatu perusahaan. Likuiditas berpengaruh terhadap kinerja keuangan (Asiah, 2011), (Hernawati, 2007), (Sunjoko, Mary Ivana, 2016), (Utami, Wikan Budi, 2016), (Febriano, 2014), (Suyono \& Gani, 2018) \& (Arisadi \& Djazuli, 2013). Likuiditas tidak berpengaruh terhadap kinerja keuangan (Noor, 2011) dan (Dwiarti, 2016).

Net Profit Margin atau margin keuntungan adalah untuk menunjukkan berapa besar persentase pendapatan bersih yang diperoleh dari setiap penjualan. Semakin besar angka yang dihasilkan, menunjukkan kinerja yang semakin baik. Net profit margin berpengaruh terhadap kinerja keuangan (Tjandra, 2015), (Noor, 2011) sedangkan net profit margin tidak berpengaruh terhadap kinerja keuangan (Wardani \& Dewi, 2015) \& (Febriano, 2014).

Leverage juga dapat didefinisikan sebagai besarnya rasio total aset dalam setiap ekuitasnya. Leverage berpengaruh terhadap kinerja keuangan (Indarti \& Extaliyus, 2013), (Tjandra, 2015), (Asiah, 2011), (Utami, Wikan Budi, 2016), (Febriano, 2014), (Arisadi \& Djazuli, 2013) \& (Isbanah, 2015). Sedangkan hasil penelitian yang menujukan bahwa leverage tidak berpengaruh terhadap kinerja keuangan (Noor, 2011), (Dwiarti, 2016) \& (Suyono \& Gani, 2018).

Firm age diukur dari lamanya perusahaan tercatat di bursa (dalam satuan tahun). Penelitian yang menyatakan bahwa firm age berpengaruh terhadap kinerja keuangan (Manik, 2011) \& (Goldwin \& Christiawan, 2017). Sedangkan penelitian yang menunjukan bahwa firm age tidak berpengaruh terhadap kinerja keuangan (Arisadi \& Djazuli, 2013).

Perusahaan besar dan go public akan mudah untuk menuju ke pasar modal (J. F. B. Weston, 1994). Hasil penelitian yang menunjukan bahwa ukuran perusahaan berpengaruh terhadap kinerja keuangan (Ahmadi, 2017), (Isbanah, 2015) \& (Arisadi \& Djazuli, 2013). Sedangkan penelitian yang menunjukan bahwa ukuran perusahaan tidak berpengaruh terhadap kinerja keuangan (Kasih, 2014) \& (Goldwin \& Christiawan, 2017).

Berdasarkan kajian teori di atas dan inkonsistensi peneltian terdahulu, maka kerangka pemikiran teoritis pada penelitian ini dapat digambarkan dengan model penelitian sebagai berikut: 


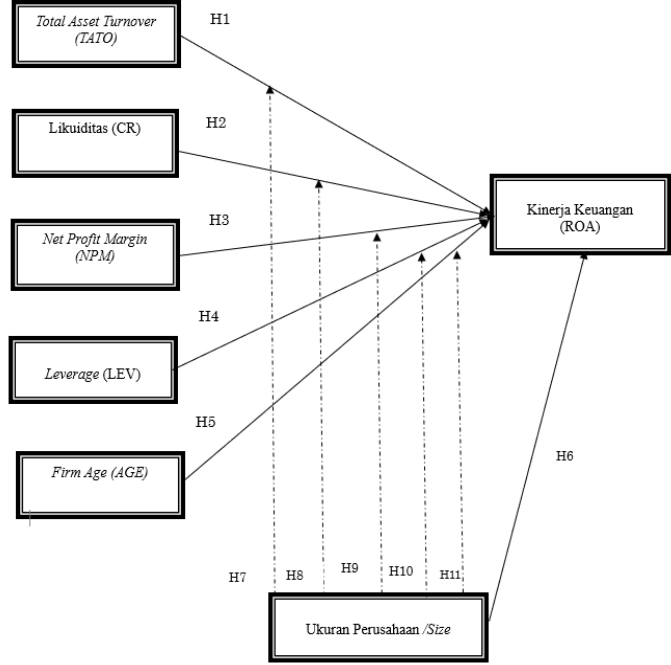

Sumber : Penelitian 2019

Gambar 2 Kerangka Pemikiran Teoritis

\section{Hipotesis}

$\mathrm{H} 1$ : Total asset turnover berpengaruh signifikan terhadap kinerja keuangan (ROA).

$\mathrm{H} 2$ : Likuiditas berpengaruh signifikan terhadap kinerja keuangan (ROA).

H3 : Net Profit Margin berpengaruh signifikan terhadap kinerja keuangan (ROA).

$\mathrm{H} 4$ : Leverage berpengaruh signifikan terhadap kinerja keuangan (ROA).

H5 : Firm age berpengaruh signifikan terhadap kinerja keuangan (ROA).

H6 : Size berpengaruh signifikan terhadap kinerja keuangan (ROA).

H7 : Size memoderasi pengaruh total asset turnover terhadap kinerja keuangan (ROA).

H8 : Size memoderasi pengaruh likuiditas terhadap kinerja keuangan (ROA).

H9 : Size memoderasi pengaruh net profit margin terhadap kinerja keuangan (ROA).

H10 : Size memoderasi pengaruh leverage terhadap kinerja keuangan (ROA).
H11 : Size memoderasi pengaruh firm age terhadap kinerja keuangan (ROA).

\section{METODE PENELITIAN}

Populasi dan Sampel

Penelitian ini menggunakan data sekunder, yaitu laporan keuangan auditan tahunan perusahaan industri manufaktur yang terdaftar di Bursa Efek Indonesia tahun 2014-2017 dan total sampel yang digunakan pada penelitian ini adalah 52 perusahaan dengan jumlah observasi sebesar 208 perusahaan. Pemilihan sampel dalam penelitian ini menggunakan metode purposive sampling, merupakan metode pengambilan sampel non-probabilitas yang disesuaikan dengan kriteria tertentu.

\section{Metode Analisis Data}

Penelitian ini menggunakan Model Persamaan Struktural atau Structural Equation Modelling (SEM) karena model penelitian ini adalah model kausalitas atau hubungan pengaruh dan variabel independen dan dependen merupakan variabel laten yang terbentuk dari beberapa konstruk. Dalam model persamaan struktural konsep dan aplikasi dengan program WarpPLS 6.0 (Kock, n.d.). WarpPLS merupakan software pemodelan persamaan struktural yang kuat untuk mengidentifikasi hubungan non linear diantara variabel laten dan mengoreksi kesesuaian nilai koefisien jalur (Latan \& Ghozali, 2017:27). Proses tahapan analisis menggunakan PLS-SEM, terdapat enam proses tahapan. Setiap tahapan akan berpengaruh tehadap tahapan selanjutnya yaitu Konseptualisasi Model, Menentukan Metoda Analisis Algorithm, Menentukan Metode Resampling, Menggambarkan Diagram Jalur, Melaporkan Hasil Analisis, Evaluasi Model (Latan \& Ghozali, 2017:47).

\section{PEMBAHASAN}

Statistik Deskriptif

\begin{tabular}{|c|c|c|c|c|c|c|}
\hline \multirow[b]{2}{*}{ Variabel } & \multicolumn{6}{|c|}{ Statistik Deskriptif } \\
\hline & Indikator & $\mathbf{N}$ & Min & $\operatorname{Max}$ & Mean & $\begin{array}{c}\text { Std } \\
\text { Deviasi }\end{array}$ \\
\hline Kinerja Keuangan & ROA & 208 & 0,001 & 0,527 & 0,084 & 0,075 \\
\hline $\begin{array}{l}\text { Total Asset } \\
\text { Turnover }\end{array}$ & TATO & 208 & 0,361 & 3,057 & 1,110 & 0,485 \\
\hline Likuiditas & $\mathrm{CR}$ & 208 & 0,514 & 15,164 & 2,875 & 2,403 \\
\hline Net Profit Margin & NPM & 208 & $-0,001$ & 0,815 & 0,087 & 0,099 \\
\hline Leverage & LEV & 208 & 0,071 & 5,200 & 0,929 & 0,827 \\
\hline
\end{tabular}




$\begin{array}{lcccccc}\text { Firm Age } & \text { AGE } & 208 & 0,000 & 36,000 & 20,88 & 8,580 \\ & & & & & 5 & \\ \text { Ukuran } & \text { SIZE } & 208 & 11,804 & 19,505 & 14,96 & 1,713\end{array}$

Perusahaan

Sumber : Data penelitian diolah dengan WarpPls 6.0

Tabel 1 diatas menunjukan jumlah sampel sebanyak 52 sampel dengan periode 4 tahun maka $\mathrm{N}=208$. Dari data 208 data ROA, nilai minimum sebesar 0.001 dan nilai maximum 0.527 . TATO dengan nilai minimum 0.361 dan nilai maximum 3.057. CR dengan nilai minimum 0.361 dan nilai maximum 15.164 . NPM dengan nilai minimum 0.001 dan nilai maximum 0.815. LEV dengan nilai minimum 0.071 dan nilai maximum 5.200. AGE dengan nilai minimum 0.000 dan nilai maximum
36.000. SIZE dengan nilai minimum 11.804 dan nilai maximum 11.804

\section{Evaluasi Model Struktural (Inner Model)}

Evaluasi inner model pada penelitian ini dilakukan dengan melihat nilai Adjusted $R$ squared, Goodness of Fit Model, $q^{2}$ predictive, effect size, dan Full Collinearity VIF serta nilai signifikansi koefisien jalur.

Tabel 2

Model Fit Indices

\begin{tabular}{|c|c|c|c|c|}
\hline Kriteria & Hasil & $\begin{array}{c}\mathbf{P}- \\
\text { values }\end{array}$ & Rule of Thumb & Keterangan \\
\hline Adjusted $^{2}$ & 0,624 & - & $\begin{array}{c}\geq 0.70 \text { (kuat) }, \geq 0.45 \\
(\text { moderate }), \leq 0.25 \\
(\text { lemah })\end{array}$ & Moderate \\
\hline $\begin{array}{l}\text { Average Path } \\
\text { Coefficient (APC) }\end{array}$ & 0,173 & $\mathrm{P}=0.003$ & $\mathrm{P}<0,05$ & Diterima \\
\hline $\begin{array}{l}\text { Average R-Square } \\
\text { (ARS) }\end{array}$ & 0,644 & $\mathrm{P}<0.001$ & $\mathrm{P}<0,05$ & Diterima \\
\hline $\begin{array}{l}\text { Average Adjusted } \\
\text { R-Square (AARS) }\end{array}$ & 0,624 & $\mathrm{P}<0.001$ & $\mathrm{P}<0,05$ & Diterima \\
\hline $\begin{array}{l}\text { Average Block VIF } \\
\text { (AVIF) }\end{array}$ & 1,749 & - & $\begin{array}{c}\leq 3.3 \text {, namun nilai } \leq 5, \\
\text { masih dapat diterima }\end{array}$ & Diterima \\
\hline $\begin{array}{l}\text { Average Full } \\
\text { Collinearity VIF } \\
\text { (AFVIF) }\end{array}$ & 2,003 & - & $\begin{array}{c}\leq 3.3 \text {, namun nilai } \leq 5, \\
\text { masih dapat diterima }\end{array}$ & Diterima \\
\hline $\begin{array}{l}\text { Tenenhaus GoF } \\
\text { (GoF) }\end{array}$ & 0,803 & - & $\begin{array}{c}\geq 0,10 \text { (kecil), } \geq 0,25 \\
\text { (menengah), } \geq 0,36 \text { (besar) }\end{array}$ & Besar \\
\hline $\begin{array}{l}\text { Statistical } \\
\text { Suppression Ratio } \\
\text { (SSR) }\end{array}$ & 0,818 & - & $\geq 0,7$ & Diterima \\
\hline $\begin{array}{l}\text { R-Squared } \\
\text { Contibution Ratio } \\
\text { (SRCR) }\end{array}$ & 0,955 & - & $\begin{array}{c}\geq 0,9, \text { Ideal }=1 \text { masih dapat } \\
\text { diterima }\end{array}$ & Diterima \\
\hline $\begin{array}{l}\text { Nonliner Brivate } \\
\text { Casuality Direction } \\
\text { Ratio (NLBCDR) }\end{array}$ & 0,909 & - & $\geq 0,7$ & Diterima \\
\hline $\begin{array}{l}\text { q2 Predictive } \\
\text { Relevance }\end{array}$ & 0,677 & - & $\begin{array}{c}\mathrm{Q} 2>0 \text { (mempunyai } \\
\text { predictive relevance), } \mathrm{Q} 2 \\
<0 \text { (tidak mempunyai } \\
\text { predictive relevance) }\end{array}$ & Diterima \\
\hline
\end{tabular}

Sumber : Data penelitian diolah dengan WarpPls 6.0 
$R$-Squared $\left(\mathrm{R}^{2}\right)$ digunakan untuk menunjukan seberapa besar persentase varian konstruk endogen dan dapat dijelaskan oleh variabel prediktor dalam model. Nilai adalah sebesar $62,40 \%$ dan termasuk kategori moderate, sedangkan sisanya $37,6 \%$ dipengaruhi oleh variabel lain.

APC memiliki indeks 0.173 dengan nilai $p$ value 0.003 . Hal ini berarti variabel endogen dan eksogen memiliki hubungan sebab akibat baik secara langsung maupun tidak langsung.

ARS memiliki indeks sebesar 0.644 dengan $p$ value < 0,001. ARS digunakan untuk mengukur akurasi kemampuan path model untuk menggambarkan pengaruh antar satu variabel independen dengan predictive value (variabel dependen).

Penelitian ini tidak terjadi multikolinearitas karena nilai AVIF yang harusnya $\leq 3,3$ sudah terpenuhi karena berdasarkan data tersebut nilai AVIF adalah 1.749. Dengan demikian inner model dapat diterima.

Full collinearity VIF digunakan untuk pengujian ada tidaknya masalah kolinearitas vertikal dan lateral. Berdasarkan hasil analisis, diketahui bahwa nilai AFVIF : 2.003 dan kurang dari $\leq 3,3$. Nilai ini menunjukan bahwa model bebas dari masalah kolinearitas vertikal, lateral dan common method bias.

Nilai Average $R$-Square (ARS) atau Qsquared $\left(\mathrm{Q}^{2}\right)$ digunakan untuk menilai validitas prediktif atau relevansi dari sekumpulan variabel laten eksogen dan variabel endogen. Output nilai ARS sebesar 0.644 .

Q-squared $\left(\mathrm{q}^{2}\right)$ Predictive Relevance digunakan untuk menilai validitas prediktif atau relevansi dari sekumpulan variabel laten endogen. Output $\mathrm{q}^{2}$ model penelitian ini menunjukan bahwa $\mathrm{q}^{2}$ bernilai lebih besar dari pada nol yaitu 0,677 sehingga dapat disimpulkan bahwa model penelitian menunjukan validitas prediktif yang baik.

\section{Hasil Uji Hipotesis}

Hipotesis dinyatakan diterima jika nilai probabilitas $(\mathrm{P})<0,05$ atau $5 \%$. Apabila salah satu atau lebih kriteria tersebut tidak terpenuhi maka hipotesis alternatif (Ha) ditolak.
Tabel 3

Hasil Output Koefisien Jalur \& Nilai Signifikansi

\begin{tabular}{lccc}
\multicolumn{1}{c}{ Variabel } & & \multicolumn{2}{c}{ Kriteria } \\
\cline { 3 - 4 } & & $\begin{array}{c}\mathrm{P}- \\
\text { coefficients }\end{array}$ & $\begin{array}{c}\mathrm{P}- \\
\text { values }\end{array}$ \\
\hline TATO & $\mathrm{X} 1$ & 0,32 & $<0,001$ \\
\hline CR & $\mathrm{X} 2$ & $-0,161$ & 0,009 \\
\hline NPM & $\mathrm{X} 3$ & 0,675 & $<0,001$ \\
\hline LEV & $\mathrm{X} 4$ & $-0,116$ & 0,045 \\
\hline AGE & $\mathrm{X} 5$ & 0,153 & 0,012 \\
\hline SIZE & $\mathrm{M}$ & $-0,038$ & 0,291 \\
\hline SIZE*TAT & $\mathrm{M} * \mathrm{X} 5$ & 0,069 & 0,158 \\
O & & & \\
\hline SIZE*CR & $\mathrm{M} * \mathrm{X} 4$ & $-0,035$ & 0,306 \\
\hline SIZE*NPM & $\mathrm{M} * \mathrm{X} 3$ & $-0,137$ & 0,022 \\
\hline SIZE*LEV & $\mathrm{M} * \mathrm{X} 1$ & $-0,047$ & 0,249 \\
\hline SIZE*AGE & $\mathrm{M} * \mathrm{X} 2$ & $-0,149$ & 0,014 \\
\hline Sumb & Data &
\end{tabular}

Sumber : Data penelitian diolah dengan WarpPls 6.0

Tabel 4

Hasil Uji Moderasi

\begin{tabular}{|c|c|c|c|c|}
\hline \multirow[t]{2}{*}{ Path } & \multicolumn{2}{|c|}{$\begin{array}{c}\text { Moderating } \\
\text { Effect }\end{array}$} & \multirow[t]{2}{*}{ Hasil } & \multirow[t]{2}{*}{$\begin{array}{c}\text { Kesimpul } \\
\text { an }\end{array}$} \\
\hline & $\beta$ & $\begin{array}{c}\mathrm{P}- \\
\text { value }\end{array}$ & & \\
\hline $\begin{array}{l}\text { SIZE*T } \\
\text { ATO }\end{array}$ & $\begin{array}{c}0,0 \\
69\end{array}$ & 0,158 & $\begin{array}{c}\text { Tidak } \\
\text { Signifikan }\end{array}$ & $\begin{array}{c}\text { Homologi } \\
\text { ser } \\
\text { Moderasi }\end{array}$ \\
\hline $\begin{array}{l}\text { SIZE*C } \\
\mathbf{R}\end{array}$ & $\begin{array}{c}- \\
0,0 \\
35\end{array}$ & 0,306 & $\begin{array}{c}\text { Tidak } \\
\text { Signifikan }\end{array}$ & $\begin{array}{l}\text { Homologi } \\
\text { ser } \\
\text { Moderasi }\end{array}$ \\
\hline $\begin{array}{l}\text { SIZE*N } \\
\text { PM }\end{array}$ & $\begin{array}{c}- \\
0,1 \\
37\end{array}$ & 0,022 & Signifikan & $\begin{array}{c}\text { Pure } \\
\text { Moderasi }\end{array}$ \\
\hline $\begin{array}{l}\text { SIZE*L } \\
\text { EV }\end{array}$ & $\begin{array}{c}- \\
0,0 \\
47\end{array}$ & 0,249 & $\begin{array}{c}\text { Tidak } \\
\text { Signifikan }\end{array}$ & $\begin{array}{c}\text { Homologi } \\
\text { ser } \\
\text { Moderasi }\end{array}$ \\
\hline $\begin{array}{l}\text { SIZE*A } \\
\text { GE }\end{array}$ & $\begin{array}{c}- \\
0,1 \\
49\end{array}$ & 0,014 & Signifikan & $\begin{array}{c}\text { Pure } \\
\text { Moderasi }\end{array}$ \\
\hline
\end{tabular}

Sumber : Data penelitian diolah dengan WarpPls 6.0

Model regresi untuk penelitian ini adalah

ROA : $\alpha+, 090$ TATO + 0,28 CR + 0,446

$\mathrm{NPM}+$ 0,029 LEV + 0,032AGE+ 0,001

SIZE+ 0,014TATO * SIZE + 0,003 CR *

SIZE+ 0,041NPM * SIZE + 0,000LEV*

SIZE $+0,023 A G E *$ SIZE $+\varepsilon$.

Pengaruh Total Asset Turnover terhadap Kinerja Keuangan (ROA). 
Hasil uji menunjukan nilai $P$-value $=<0,001$ $\leq 0,05$ yang artinya memiliki pengaruh signifikan dengan nilai $\mathrm{R}^{2}$ dapat dilihat di effect size, dimana nilainya $0,090(\geq 0,02$ (kecil), $\geq 0,015$ (menengah), $\geq 0,35$ (besar) yang termasuk kategori kecil pengaruhnya. Semakin tinggi efisien penggunaan asset dan semakin cepat pengembalian dana dalam bentuk kas (Halim, 2007). Jadi dapat disimpulkan jika semakin efektif perusahaan menggunakan aktivanya menghasilkan penjualan bersihnya menunjukan semaik baik kinerja yang dicapai oleh perusahaan.

Hasil hipotesis ini mendukung penelitian terdahulu yaitu penelitian dari (Tjandra, 2015) , (Asiah, 2011), (Noor, 2011), (Haryo, Mercky, Amzul Rifin, 2017), (Dwiarti, 2016), (Goldwin \& Christiawan, 2017) \& (Suyono \& Gani, 2018) menunjukan bahwa perputaran total aset berpengaruh signifikan terhadap kinerja keuangan.

\section{Pengaruh Likuiditas terhadap Kinerja Keuangan (ROA).}

Hasil uji menunjukan nilai $P$-value $=0,009 \leq$ 0,05 yang artinya memiliki pengaruh signifikan, dengan nilai $\mathrm{R}^{2}$ dapat dilihat di effect size, dimana nilainya $0,028(\geq 0,02$ (kecil), $\geq 0,015$ (menengah), $\geq 0,35$ (besar) yang termasuk kategori kecil pengaruhnya. Likuiditas perusahaan berbanding terbalik dengan profitabilitas (Van \& Wachowicz, 2009). Maksudnya, semakin tinggi likuiditas perusahaan maka kemampuan perusahaan untuk menghasilkan laba semakin rendah. Semakin tinggi likuditas semakin besar kemampuan perusahaan untuk membayar kewajiban jangka pendek.

Hipotesis ini mendukung penelitian terdahulu yaitu penelitian dari (Asiah, 2011), (Hernawati, 2007), (Sunjoko, Mary Ivana, 2016), (Utami, Wikan Budi, 2016), (Febriano, 2014), (Suyono \& Gani, 2018) \& (Arisadi \& Djazuli, 2013) menujukan hasil bahwa likuiditas berpengaruh signifikan terhadap kinerja keuangan.

\section{Pengaruh Net Profit Margin terhadap Kinerja Keuangan (ROA).}

Hasil uji menunjukan nilai $P$-value $=<0,001$ $\leq 0,05$ yang artinya memiliki pengaruh signifikan dengan nilai $\mathrm{R}^{2}$ dapat dilihat di effect size, dimana nilainya $0,446(\geq 0,02$ (kecil), $\geq 0,015$ (menengah), $\geq 0,35$ (besar) yang termasuk katerogi besar pengaruhnya. Net Profit Margin merupakan rasio antara laba bersih setelah pajak terhadap penjualan. "Semakin tinggi Net Profit Margin, semakin baik operasi suatu perusahaan" (Syamsuddin, 2013.) Artinya semakin tinggi persentase laba bersih setelah pajak yang dihasilkan terhadap penjualan, maka semakin baik kinerja keuangan perusahaan tersebut.

Hipotesis ini mendukung hasil penelitian dari (Tjandra, 2015), (Noor, 2011) menujukan hasil bahwa net profit margin berpengaruh signifikan terhadap kinerja keuangan.

\section{Pengaruh Leverage terhadap Kinerja Keuangan (ROA).}

Hasil uji menunjukan nilai $P$-value $=0,045 \leq$ 0,05 yang artinya memiliki pengaruh signifikan dengan nilai $\mathrm{R}^{2}$ dapat dilihat di effect size, dimana nilainya $0,029(\geq 0,02$ (kecil), $\geq 0,015$ (menengah), $\geq 0,35$ (besar) yang termasuk kategori kecil pengaruhnya. Perusahaan dengan rasio leverage yang rendah memiliki resiko rugi yang lebih kecil jika kondisi ekonomi sedang menurun, tetapi juga memiliki hasil pengembalian yang lebih rendah jika kondisi ekonomi membaik. Sebaliknya, perusahaan dengan rasio leverage yang tinggi mengemban resiko rugi yang besar, tetapi juga memiliki kesempatan untuk memperoleh laba yang tinggi.

Hipotesis ini mendukung hasil penelitian dari (Indarti \& Extaliyus, 2013), (Tjandra, 2015), (Asiah, 2011), (Utami, Wikan Budi, 2016), (Febriano, 2014), (Isbanah, 2015) \& (Arisadi \& Djazuli, 2013) menujukan hasil bahwa leverage berpengaruh signifikan terhadap kinerja keuangan.

\section{Pengaruh Firm Age terhadap Kinerja Keuangan (ROA).}

Hasil uji menunjukan nilai $P$-value $=0,012 \leq$ 0,05 yang artinya memiliki pengaruh signifikan dengan nilai $\mathrm{R}^{2}$ dapat dilihat di effect size, dimana nilainya $0,032(\geq 0,02$ (kecil), $\geq 0,015$ (menengah), $\geq 0,35$ (besar) yang termasuk kategori kecil pengaruhnya. Perusahaan yang telah lama berdiri pada umumnya memiliki profitabilitas yang lebih stabil dibandingkan dengan perusahaan yang 
masih baru berdiri dengan umur yang singkat. Perusahaan yang memiliki umur yang lebih lama akan meningkatkan labanya karena adanya pengalaman dari manajemen sebelumnya dalam mengelola perusahaannya. Hipotesis ini mendukung hasil penelitian dari (Manik, 2011) \& (Goldwin \& Christiawan, 2017) menunjukan bahwa ukuran perusahaan berpengaruh signifikan terhadap kinerja keuangan.

\section{Pengaruh Size terhadap Kinerja Keuangan (ROA).}

Hasil uji menunjukan nilai $P$-value $=0,291 \geq$ 0,05 yang artinya tidak memiliki pengaruh signifikan dengan nilai $\mathrm{R}^{2}$ dapat dilihat di effect size, dimana nilainya $0,001 \quad(\geq 0,02$ (kecil), $\geq 0,015$ (menengah), $\geq 0,35$ (besar) yang termasuk kategori sangat kecil pengaruhnya. Menurut (Munawir, 2007) menyebutkan bahwa perusahaan-perusahaan yang memiliki ukuran yang lebih besar memiliki dorongan yang kuat untuk menyajikan tingkat profitabilitas yang tinggi dibandingkan dengan perusahaan-perusahaan yang lebih kecil karena perusahaan yang lebih besar diteliti dan dipandang dengan lebih kritis oleh para investor.

Hipotesis ini mendukung penelitian terdahulu yaitu penelitian dari (Kasih, 2014) \& (Goldwin \& Christiawan, 2017) menunjukan bahwa ukuran perusahaan tidak berpengaruh terhadap kinerja keuangan.

Size Tidak Memoderasi Pengaruh Total Asset Turnover terhadap Kinerja Keuangan (ROA).

Hasil uji menunjukan nilai $P$-value $=0,158 \geq$ 0,05 yang artinya tidak memiliki pengaruh signifikan dan nilai $\mathrm{R}^{2}$ dapat dilihat di effect size, dimana nilainya $0,014(\geq 0,02$ (kecil), $\geq$ 0,015 (menengah), $\geq 0,35$ (besar) yang termasuk kategori sangat kecil pengaruhnya. Hal ini berarti semakin tinggi efisien penggunaan asset dan semakin cepat pengembalian dana dalam bentuk kas tidak tergantung kepada ukuran perusahaan. Dengan demikian teori signal tidak memberikan sinyal yang baik terhadap pengaruh total asset turnover terhadap kinerja keuangan.

\section{Size Tidak Memoderasi Pengaruh Likuiditas terhadap Kinerja Keuangan (ROA).}

Hasil uji menunjukan nilai $P$-value $=0,306 \geq$ 0,05 yang artinya tidak memiliki pengaruh signifikan dan nilai $\mathrm{R}^{2}$ dapat dilihat di effect size, dimana nilainya $0,003(\geq 0,02$ (kecil), $\geq$ 0,015 (menengah), $\geq 0,35$ (besar) yang termasuk kategori sangat kecil pengaruhnya. Pada industri manufaktur, dari tahun ke tahun sejak 2011 mengalami penurunan dan tidak mencapai batas nilai likuiditas. Penurunan likuiditas diakibatkan oleh nilai hutang lancar yang terus meningkat tanpa diseimbangi dengan peningkatan aktiva lancar dan menurunkan kepercayaan investor. Kesimpulan dari hipotesis ini adalah kemampuan perusahaan dalam memenuhi kewajiban jangka pendek dengan aktiva lancar yang dimilikinya tidak dipengaruhi oleh ukuran perusahaan.

\section{Size Memoderasi Pengaruh Net Profit Margin terhadap Kinerja Keuangan (ROA).}

Hasil uji menunjukan nilai $P$-value $=0,022 \leq$ 0,05 yang artinya memiliki pengaruh signifikan dengan nilai $\mathrm{R}^{2}$ dapat dilihat di effect size, dimana nilainya $0,041(\geq 0,02$ (kecil), $\geq 0,015$ (menengah), $\geq 0,35$ (besar) yang termasuk kategori kecil pengaruhnya. Semakin tinggi persentase laba bersih setelah pajak yang dihasilkan terhadap penjualan / net profit margin, maka semakin baik kinerja keuangan perusahaan tersebut. Hal ini dikarenakan semakin luas atau besar suatu ukuran perusahaan maka akan semakin tinggi jumlah produktifitas, produk dan penjualan yang dihasilkan.

\section{Size Tidak Memoderasi Pengaruh Leverage terhadap Kinerja Keuangan (ROA).}

Hasil uji menunjukan nilai $P$-value $=0,249 \geq$ 0,05 yang artinya tidak memiliki pengaruh signifikan dengan nilai $\mathrm{R}^{2}$ dapat dilihat di effect size, dimana nilainya $0.000(\geq 0,02$ (kecil), $\geq 0,015$ (menengah), $\geq 0,35$ (besar) yang termasuk kategori sangat kecil pengaruhnya. Pada industri manufaktur contohnya perusahaan mobil, dengan ukuran perusahaan yang besar maka memerlukan banyak peralatan, oleh karenanya mengakibatkan tingkat leverage tinggi, biaya 
cost naik, biaya overhead naik . Kenaikan biaya tersebut terjadi disaat kondisi ekonomi sedang melemah sejak tahun 2011, maka akan menurunkan penjualan sehingga mengakibatkan profitabilitas turun dan investor kurang tertarik untuk menanamkan saham di perusahaan tersebut. Kesimpulan dari hipotesis ini adalah perusahaan yang penggunaan hutang yang kecil tidak berpengaruh terhadap seberapa besar ukuran dari suatu perusahaan.

Size Memoderasi Pengaruh Firm Age terhadap Kinerja Keuangan (ROA).

Hasil uji menunjukan nilai $P$-value $=0,014 \leq$ 0,05 yang artinya memiliki pengaruh signifikan dengan nilai $\mathrm{R}^{2}$ dapat dilihat di effect size, dimana nilainya $0,023(\geq 0,02$ (kecil), $\geq 0,015$ (menengah), $\geq 0,35$ (besar) yang termasuk kategori kecil pengaruhnya. perusahaan yang telah lama berdiri dan memiliki ukuran yang besar pada umumnya memiliki profitabilitas yang lebih stabil dibandingkan dengan perusahaan yang masih baru berdiri dengan umur yang singkat.

\section{PENUTUP}

Penelitian ini bertujuan untuk mengetahui bagaimana determinasi kinerja keuangan dengan size sebagai moderasi pada perusahaan industri manufaktur yang terdaftar di Bursa Efek Indonesia periode 2014-2017 dengan variabel independen sebagai berikut total asset turnover, likuiditas, net profit margin, leverage dan firm age. Penelitian ini menggunkan Model Persamaan Struktural atau Structural Equation Modelling (SEM) WarpPLS 6.0. Berdasarkan hasil dan pembahasan yang telah dilakukan pada bab sebelumnya, maka penulis mengambil kesimpulan sebagai berikut : Total asset turnover berpengaruh signifikan terhadap kinerja keuangan yang diproxykan dengan ROA pada perusahaan industri manufaktur pada periode 2014-2017. Likuiditas berpengaruh signifikan terhadap kinerja keuangan yang diproxykan dengan ROA pada perusahaan industri manufaktur pada periode 2014-2017. Net profit margin berpengaruh signifikan terhadap kinerja keuangan yang diproxykan dengan ROA pada perusahaan industri manufaktur pada periode 2014-2017.
Leverage berpengaruh signifikan terhadap kinerja keuangan yang diproxykan dengan ROA pada perusahaan industri manufaktur pada periode 2014-2017. Firm age berpengaruh signifkan terhadap kinerja keuangan yang diproxykan dengan ROA pada perusahaan industri manufaktur pada periode 2014-2017. Size tidak memiliki pengaruh terhadap kinerja keuangan yang diproxykan dengan ROA pada perusahaan industri manufaktur pada periode 2014-2017. Size tidak memoderasi pengaruh total asset turnover terhadap kinerja keuangan yang diproxykan dengan ROA pada perusahaan industri manufaktur pada periode 2014-2017. Size tidak memoderasi pengaruh likuiditas terhadap kinerja keuangan yang diproxykan dengan ROA pada perusahaan industri manufaktur pada periode 2014-2017. Size memoderasi pengaruh net profit margin terhadap kinerja keuangan yang diproxykan dengan ROA pada perusahaan industri manufaktur pada periode 2014-2017. Size tidak memoderasi pengaruh leverage terhadap kinerja keuangan yang diproxykan dengan ROA pada perusahaan industri manufaktur pada periode 2014-2017. Size memoderasi pengaruh firm age terhadap kinerja keuangan yang diproxykan dengan ROA pada perusahaan industri manufaktur pada periode 2014-2017.

\section{REFERENSI}

Ahmadi, M. (2017). Analisis Pengaruh Good Corporate Governance (GCG) dan Ukuran Perusahaan (Size) Terhadap Kinerja Keuangan Pada Sektor Perbankan. STIE PERBANAS SURABAYA.

Asiah, A. N. (2011). Analisis Faktor-Faktor yang Memprngaruhi Kinerja Keuangan Industri Tekstil yang terdaftar pada Bursa Efek Indonesia. Socioscientia Jurnal Ilmu-Ilmu Social, 3(2).

Chang, S.J. and Hong, J. (2002). How Much does the Business Group Matter in Korea? Strategic Management Journal, 23 (3), 265-274.

Dwiarti, R. (2016). Evaluasi faktor-faktor yang mempengaruhi profitabilitas pada perusahaan manufaktur yang terdaftar di BEI. Jurnal SosioHumaniora, 4(5). 
Febriano, V. H. (2014). Pengukuran Kinerja Keuangan dengan Menggunakan Metode Return On Asset (ROA) dan Economic Value Added (EVA) Pada PT.XL Axiata Tbk.

Goldwin, J., \& Christiawan, Y. J. (2017). Pengaruh penerapan corporate governance terhadap kinerja keuangan perusahaan dengan ukuran perusahaan dan umur perusahaan sebagai variabel kontrol. Business Accounting Review, 5(2), 217-228.

Halim, A. (2007). Manajemen Keuangan Bisnis. Bogor: Ghalia Indonesia.

Haryo, Mercky, Amzul Rifin, and B. S. (2017). Factors Affecting Profitability on Animal Feed Companies in Indonesia." Agro Ekonomi 28.2: 289308.

Hernawati, I. (2007). Analisis Pengaruh Efesiensi Modal, Likuiditas dan Solvabilitas Terhadap Profitabilitas (Studi Kasus Pada Industri Barang Konsumsi Di Bursa Efek Jakarta). Universitas Negeri Semarang.

Indarti, M. G. K., \& Extaliyus, L. (2013). Pengaruh Corporate Gorvernance Preception Index (CGPI), Struktur Kepemilikan, dan Ukuran Perusahaan Terhadap Kinerja Keuangan. Jurnal Bisnis Dan Ekonomi, 20(2).

Isbanah, Y. (2015). Pengaruh Esop, Leverage, And Ukuran Perusahaan Terhadap Kinerja Keuangan Perusahaan Di Bursa Efek Indonesia. Jurnal Riset Ekonomi Dan Manajemen, 15(1), 28-41.

Kasih, A. P. (2014). Pengaruh Good Corporate Governance Dan Ukuran Perusahaan Terhadap Kinerja Perusahaan (Studi Empiris Pada Perusahaan yang Terdaftar di BEI Tahun 2009-2011). Muhammadiyah Surakarta.

Keown, A. J., Martin, J. D., Petty, J. W., \& Scott, D. F. (2008). JR. 2005. Financial Management.

Kock, N. (2009). (n.d.). Warp PLS 1.0 User Manual. ScriptWarp Systems, Laredo Texas. Retrieved from http://www.scriptwarp.com/ warppls/UserManual.pdf.

Kusuma, H. (2005). Size Perusahaan dan Profitabilitas: Kajian Empiris terhadap
Perusahaan Manufaktur yang Terdaftar di Bursa Efek Jakarta. Economic Journal of Emerging Markets, 10(1).

Latan, H., \& Ghozali, I. (2017). Partial Least Squares: Konsep, Metode dan Aplikasi Menggunakan Program WarpPLS 5.0 (Edisi Keti). Semarang: Badan Penerbit Universitas Diponegoro.

Maith, H. A. (2013). Analisis Laporan Keuangan dalam Mengukur Kinerja Keuangan pada PT. Hanjaya Mandala Sampoerna Tbk. Jurnal EMBA: Jurnal Riset Ekonomi, Manajemen, Bisnis Dan Akuntansi, 1(3).

Manik, T. (2011). Analisis pengaruh kepemilikan manajemen, komisaris independen, komite audit, umur perusahaan terhadap kinerja keuangan. JEMI, 2(2), 25-36.

Martani D. (2012). Akuntansi Keuangan Menengah Berbasis PSAK. Jakarta: Salemba Empat.

Munawir. (2004). Analisis Laporan Keuangan Edisi Keempat Cetakan Kelima. Yogyakarta: Liberty Jogya.

Munawir. (2007). Analisis Laporan Keuagan, Edisi Keempat. Yogyakarta: Liberty. Pachta W.

Noor, J. (2011). Metodologi Penelitian, Penerbit Kencana, Jakarta.

Riyanto, B. (2001). Dasar-dasar Pembelanjaan Perusahaan Edisi 4. Yogyakarta: BPFE.

Sawir, A. (2001). Analisis Laporan Keuangan dan Perencanaan Keuangan Perusahaan. Jakarta. Gramedia Pustaka Utama.

Sugiyono, E. W. (2007). Statistika Penelitian, Edisi I, Bandung: Alfabeta.

Sundjaja, R., \& Barlian, I. (2003). Manajemen Keuangan 2 Edisi Keempat. Bandung: Literata Lintas Media.

Sunjoko, Mary Ivana, and E. J. A. (2016). Effects of inventory turnover, total asset turnover, fixed asset turnover, current ratio and average collection period on profitability." Jurnal Bisnis dan Akuntansi 18.1 (2016): 79-83.

Suyono, S., \& Gani, E. A. (2018). Analisi Pengaruh Rasio Likuiditas, Rasio Aktivitas, Rasio Modal Kerja dan Rasio Solvabilitas Terhadap Profitabilitas Pada Perusahaan Telekomunikasi Yang Terdaftar di BEI (Periode 2011-2016). PROCURATIO (Jurnal Ilmiah 
Manajemen), 6(1), 111-121.

Syamsuddin, L. 2013. (n.d.). Manajemen Kuangan Perusahaan Edisi Baru. Jakarta: Rajawali Pers.

Tjandra, E. (2015). Pengaruh Good Corporate Governance Terhadap Leverage Dan Profitabilitas Pada Perusahaan Property Dan Real Estate Di Indonesia.

Utami, Wikan Budi, and S. L. P. (2016). Pengaruh Likuiditas, Solvabilitas, dan Manajemen Aset Terhadap Kinerja Keuangan Pada Perusahaan Go Publik Yang Terdaftar Dalam Kompas 100 di Indonesia." Jurnal Akuntansi dan Pajak 17.01 (2016).

Van, H. J. C., \& Wachowicz, J. M. (2009). Prinsip-Prinsip Manajemen Keuangan. alih bahasa Dewi Fitriasari dan Deny A. Kwary. Jakarta: Salemba.

Wardani, A. K., \& Dewi, F. R. (2016). Analisis Struktur Modal terhadap Kinerja Keuangan Perusahaan Sektor Utama yang Terdaftar di Indeks LQ45 Bursa Efek Indonesia. Jurnal Manajemen dan Organisasi, 6(2), 134148.

Wardani, A. K., \& Dewi, F. R. (2015). Analisis Struktur Modal terhadap Kinerja Keuangan Perusahaan Sektor Utama yang Terdaftar di Indeks LQ45 Bursa Efek Indonesia. Jurnal Manajemen Dan Organisasi, 6(2), 134148.

Watts, R. L., \& Zimmerman, J. L. (1986). Positive accounting theory.

Weston, J. F. B. (1994). Dasar Managemen Keuangan. Jakarta: Erlangga. Dasar Managemen Keuangan. Jakarta: Erlangga.

Weston, J. F., \& Brigham, E. F. (1989).
Package Preview: Essentials of Managerial Finance. Dryden Press.

Widiyanti, M., \& Elfina, F. D. (2015). Pengaruh Financial Leverage terhadap Profitabilitas pada Perusahaan Sub Sektor Otomotif dan Komponen yang Terdaftar di Bursa Efek Indonesia. Jurnal Manajemen dan Bisnis Sriwijaya, Vol.13 No.1.Ali, Mohammad. 2014. Relationship between Financial Leverage an.

\section{BIODATA PENULIS}

Peni Setiyo Wati, Pendidikan S1 di Institut STIAMI Jakarta - lulus tahun 2015, jurusan Administrasi Publik, kosentrasi Perpajakan dan Pendidikan S2 di Universitas Pancasila jurusan Magister Akuntansi - lulus tahun 2019. Menjadi Manager Accounting \& Tax di perusahaan swasta PMA sejak tahun 2016.

JMV Mulyadi, Dosen di Universitas Pancasila. Pendidikan S1 di Universitas Trisakti - lulus tahun 1986. Pendidikan S2 di Sekolah Tinggi Manajemen Ppm tahun 1996. Pendidikan S3 di Universitas Persada Indonesia (YAI) tahun 2006. Menjadi Ketua Program Magister Akuntansi di Universitas Pancasila dan Dosen S2 di IBS.

Widarto Rachbini, Dosen di Universitas Pancasila. Pendidikan S1 di Institut Pertanian Bogor - lulus tahun 1986. Pendidikan S2 di Universitas Indonesia tahun 1997. Pendidikan S3 di Institut Pertanian Bogor tahun 2005. Aktif mengajar sejak tahun 2015. Menjadi sekretaris dan dosen program doktoral di Universitas

Pancasil 